\title{
Stage IV Small Intestinal Cancer AJCC v7
}

National Cancer Institute

\section{Source}

National Cancer Institute. Stage IV Small Intestinal Cancer A/CC v7. NCI Thesaurus. Code C5810.

Stage IV includes: Any T, Any N, M1. M1: Distant metastasis. (AJCC 7th ed.) 